\title{
Penggunaan Media Papan Flanel untuk Meningkatkan Kemampuan Mengenal Huruf Vokal dan Konsonan pada Anak Kelompok B di TKK Rherhedja 2
}

\begin{tabular}{|c|c|}
\hline & $\begin{array}{c}\text { Maria Magadalena Mery }{ }^{{ }^{*}} \\
{ }^{1} \text { TKK Rherhedja } 2 \text { Ende } \\
\text { Ialan Sultan Hasanudin, Ende Timur,Kab. Ende, Nusa Tenggara Timur } \\
{ }^{*} \text { Corresponding Author: mervmaga@gmail.com }\end{array}$ \\
\hline Info Artikel & Abstract \\
\hline $\begin{array}{l}\text { Sejarah Artikel: } \\
\text { Diterima: } 27 / 01 / 2020 \\
\text { Direvisi: } 19 / 03 / 2020 \\
\text { Disetujui: } 25 / 03 / 2020\end{array}$ & $\begin{array}{l}\text { The research aims to: (1) know how to use the media on the flannel board in learning the } \\
\text { recognition of vowels and consonants in group B TKK Rherhedja children. (2) Improve the } \\
\text { ability of children in group B TKK Rherhedja } 2 \text { in recognizing vowels and consonants } \\
\text { through the media flannel board. This research is a class action research (CAR), which is } \\
\text { implemented in } 2 \text { cycles. The data collection techniques used are observation and }\end{array}$ \\
\hline $\begin{array}{l}\text { Keywords: } \quad \text { Media } \\
\text { Board Flannel, Ability } \\
\text { to Recognize Vowels } \\
\text { and } \quad \text { Consonants }\end{array}$ & $\begin{array}{l}\text { documentation. The subject of this study was the children of group B at TTK Rherhedja } 2 \\
\text { with a total of } 18 \text { people. The results of the research proved, (1) Media Flannel board } \\
\text { already used well in learning to children group B in TTK Rherhedja } 2 \text {. On cycle I, the } \\
\text { percentage of applicability rate is } 75 \% \text { in good category and on cycle II increased to a very } \\
\text { good category with a percentage of } 95 \% \text {. (2) Ability to recognize letters in group B Children } \\
\text { in TKK Rherhedja } 2 \text { of the } 18 \text { children on the pre cycle, newly developed children were } 6 \\
\text { peoples or } 33.33 \% \text {, children who started to grow were } 9 \text { peoples or } 50 \% \text {, children develop } \\
\text { as expected were } 3 \text { peoples or } 16.67 \% \text { and very good child was } 0 \% \text {. After using the flannel } \\
\text { board media, there was an increase in cycle I: children who were just developing } 0 \% \text {, } \\
\text { children who were starting to develop were } 6 \text { peoples or } 33.33 \% \text {, children developing as } \\
\text { expected were } 12 \text { peoples or } 66,67 \% \text {. In Cycle II there was an increase in the ability to } \\
\text { recognize letters as follows: the percentage of children newly developing was } 0 \% \text {, the } \\
\text { percentage of children starting to develop was } 0 \% \text {, the percentage of children developing as } \\
\text { expected was } 44.44 \% \text { or } 8 \text { peoples, and very well developed children was } 55.56 \% \text { or } 10 \\
\text { peoples. Thus, the Flannel Board Media can improve the ability of group B children in } \\
\text { recognizing vowels and consonants in TKK Rherhedja }\end{array}$ \\
\hline
\end{tabular}

\section{Abstrak}

Penelitian ini bertujuan untuk; (1) mengetahui bagaimana penggunaan media papan flanel dalam pembelajaran pengenalan huruf vokal dan konsonan pada anak kelompok B TKK Rherhedja, (2) meningkatkan kemampuan anak kelompok B TKK Rherhedja 2 dalam mengenal huruf vokal dan konsonan melalui media papan flanel. Penelitian ini adalah penelitian tindakan kelas (PTK) yang dilksanakan dalam 2 siklus. Teknik pengumpulan data yang digunakan adalah Observasi dan dokumentasi. Subjek penelitian ini adalah anak kelompok B di TTK Rherhedja 2 yang berjumlah 18 orang. Hasil penelitian membuktikan, (1) Media papan flanel sudah dapat digunakan dengan baik dalam pembelajaran pada anak kelompok B di TTK Rherhedja 2. Pada siklus I, persentase tingkat penerapan adalah $75 \%$ dalam kategori baik dan pada siklus II meningkat menjadi kategori sangat baik dengan persentase $95 \%$. (2) Kemampuan mengenal huruf pada anak kelompok B di TKK Rherhedja 2 Dari 18 anak pada Pra siklus anak yang baru berkembang (BB) 6 orang atau $33,33 \%$, anak yang mulai berkembang (MB) 9 orang atau 50\%, anak berkembang sesuai harapan (BSH) 3 orang atau 16,67\% dan anak berkembang sangat baik (BSB) $0 \%$. Setelah digunakan media papan flannel, pada siklus I terjadi peningkatan: anak yang baru berkembang (BB) $0 \%$, anak yang mulai berkembang (MB) 6 orang atau 33,33\%, anak berkembang sesuai harapan (BSH) 12 orang atau 66,67\%. Pada Siklus II terjadi peningkatan kemampuan mengenal huruf sebagai berikut: persentase anak yang baru berkembang (BB) adalah $0 \%$, persentase anak yang mulai berkembang (MB) adalah $0 \%$, persentase anak berkembang sesuai harapan (BSH) adalah $44.44 \%$ atau8 orang, dan persentase anak berkembang sangat baik (BSB) adalah 55,56\% atau 10 orang. Dengan demikian Media Papan Flanel dapat meningkatkan kemampuan anak kelompok B dalam mengenal huruf vokal dan konsonan di TKK Rherhedja 2. 


\section{PENDAHULUAN}

Anak usia dini adalah individu yang berbeda, unik dan memiliki karakteristik sendiri sesuai tahapan usianya. Perkembangan berpikir Anak Usia Dini sangat pesat. Menurut Undang-Undang Nomor 20 Tahun 2013 tentang Sistim Pendidikan Nasional mengamanatkan dengan tegas perlu adanya penanganan anak usi dini, hal tersebut dapat dilihat pada pasal 1 butir 14 yang menyatakan bahwa : Pendidikan Anak Usia Dini adalah suatu upaya pembinaan yang di tunjukan kepada anak sejak lahir sampai dengan usia enam tahun, yang dilakukan dengan pemberian rangsangan Pendidikan untuk membantu pertumbuhan dan perkembangan Jasmani dan Rohani agar memiliki kesiapan dalam memasuki pendidikan lebih lanjut (Kemendikmas,2013:1).

Dalam masa-masa ini segala potensi dan kemampuan anak dapat dikembangkan secara optimal, tentunya dengan bantuan orang-orang yang berada di lingkungan anak-anak tersebut, misalnya bantuan orang tua dan guru taman kanak-kanak. Salah satu kemampuan anak yang sedang berkembang saat usia taman kanakkanak adalah kemampuan berbahasa. Penguasaan bahasa sangat erat kaitannya dengan kemampuan kognitif anak. Sistematika berbicara anak, sistematika dalam berpikir, termasuk dalam pengembangan bahasa selain dari berbicara adalah kemampuan menyimak, membaca dan menulis.

Perkembangan bahasa anak usia taman kanak-kanak memang masi jauh dari sempurna. Namun demikian potensinya dapat dirangsang lewat komunikasi yang aktif dengan menggunakan bahasa yang baik dan benar. Bahasa yang digunakan oleh orang-orang yang dekat dengan anak- anak akan mempengaruh ketrampilan anak dalam berbicara dan berkomunkasi. Di taman kanak-kanak guru adalah salah seorang yang dapat mempengaruhi perkembangan bahasa anak. Guru taman kanak-kanak harus dapat mengupayakan berbagai strategi pembelajaran yang dapat mengembangkangkan kemampuan bahasa anak, salah satunya dengan menggunakan media papan flanel.
Sebagai guru perlu diingat bahwa kemampuan bahasa itu sangat penting bagi anak. Oleh sebab itu guru perlu melakukan pengembangan membaca bagi anak. Kemampuan membaca bisa juga disebut dengan ketrampilan membaca. Karena itu memiliki ketrampilan membaca tersebut diperlukan pelatihan,praktek dan pembiasaan. Guru perlu memperhatikan upaya untuk mengembangkan kemammpuan membaca pada anak taman kanak- kanak dan apa-apa saja yang perlu diperhatikan dalam pengembangan membaca pada usia taman kanak - kanak. Salah satu poin yang diperhatikan adalah mengenal huruf vokal dan konsonan. Materi ini menjadi dasar bagi anak- anak dalam mengembangkan kemampuan membacanya.

Berdasarkan data hasil observasi didalam kelas guru menemukan permasalahan sehubungan dengan materi yang diberikan,dimana $50 \%$ anak, belum mengenal secara baik huruf vokal dan konsonan. Dengan prosentase yang cukup besar ini jika tidak diperhatikan secara serius akan berdampak pada kemampuan membaca anak pada kelas rendah di tingkat sekolah dasar. Hasil Observasi Guru menemukan juga bahwa, ketika guru menulis huruf - huruf dipapan tulis, khusus huruf vokal ( a, i, u, e, o ) dan konsonan yang mudah disebut atau dibunyikan oleh anak usia dini (b, c, d, g,h,j,k,l,m,n, p, $r, s, t$, ) sebagian besar anak belum mampu mengenal huruf-huruf tersebut.

Realitas demikian mendorong guru melakukan refleksi menemukan akar permasalahan yang tepat sebagai upaya untuk meningkatkan kemampuan anak untukmengenal huruf vokal dan konsonan.

Hasil refleksi ditemukan beberapa fakta bahwa, guru belum makasimal menggunakan alat peraga, dan metode yang dipakai kurang tepat. Berdasarkan alur berpikir di atas, dapat dirumuskan judul penelitian ini adalah: Penggunaan Media Papan Flanel untuk Meningkatkan Kemamapuan Mengenal Huruf Vokal dan Kosonan pada anak Kelompok B TK Rherhedja 2.

\section{METODE PENELITIAN}

Penelitian ini termasuk jenis penelitian tindakan kelas (PTK) yang dilksanakan dalam 
2 siklus. Teknik pengumpulan data yang digunakan adalah (1) Observasi, (2) dan (2) dokumentasi. Subjek penelitian ini adalah siswa kelas VIII B berjumlah 18 orang. Teknik analisis data yang digunakan menggunakan model oleh Kemmis \& McTaggart, dalam (Arikunto,2010).

\section{HASIL DAN PEMBAHASAN}

\section{A. Hasil Penelitian}

\section{Deskripsi Awal Sebelum Pelaksanaan Tindakan.}

Penelitian ini dilaksanakan di Kelas B TKK Rherhedja di Ende. Jumlah anak 18 orang. Penelitian ini tepatnya dilakukan pada bulan Sepetember 2019 yang terdiri dari dua siklus.Siklus pertama terdiri dari satu kali pertemuan dengan materi mengenal huruf dan siklus II terdiri dari satu kali pertemuan dengan materi yang sama.

Kegiatan pembelajaran dilaksanakan dengan menggunakan media papa flanel sesuai dengan RPPH. Selanjutnya untuk melihat perkembangan anak setelah penerapan media papan flanel guru memberikan kesempatan kepada anak untuk menempel huruf pada papan flanel. Berikut ini akan disajikan data hasil tes pengenalan huruf pada anak kelompok B pada kegiatan pra siklus sbb:

Tabel 1.

Hasil pra siklus Pengenalan huruf Pada Anak Kelompok B TKK Rherhedja 2

\begin{tabular}{ccccc}
\hline Nama anak & \multicolumn{3}{c}{ Nilai } \\
& BB & MB & BSH & BSB \\
\hline MHR & & $* * 2$ & & \\
KSO & & $* * 2$ & & \\
MKJ & & $* * 2$ & $* * * 3$ & \\
EAM & & & & \\
YYP & $* 1$ & & \\
PLI & & $* * 2$ & \\
FAT & $* 1$ & & \\
EKR & & $* * 2$ & \\
YBP & & $* * 2$ & \\
AMS & $* 1$ & & \\
LAN & $* 1$ & & \\
FJW & & $* * 2$ & $* * 3$ \\
AMG & & & \\
MGS & $* 1$ & & \\
MFD & & $* * 2$ & \\
DBB & & $* * 2$ & $* * * 3$ \\
FVP & & & \\
FJW & $* 1$ & & \\
\hline Jumlah & 6 & 9 & 3 \\
\hline
\end{tabular}

Ket: BB: (Belum Berkembang *1) MB (mulai berkembang**2), BSH Berkembang sesuai Harapan***3) BSB (Berkembang sangat baik****4)

Berdasarkan data pra siklus di atas dapat diketahui bahwa kemampuan pengenalan huruf anak kelompok B adalah sebagai berikut: belum berkembang atau $* 1$ sebanyak 6 orang atau $31.57 \%$, Mulai berkembang 9 orang atau $50 \%$ dan Baru sesuai harapan 3 orang atau $15.78 \%$ serta berkembang sangat baik 0 anak.

Berdasarkan data di atas maka refkelsi peneliti adalah menggunakan media papan flanel untuk meningkatkan kemampuan anak dalam mengenal huruf. Selanjutnya data pra siklus itu dapat digambar dalam bentuk diagram sbb:

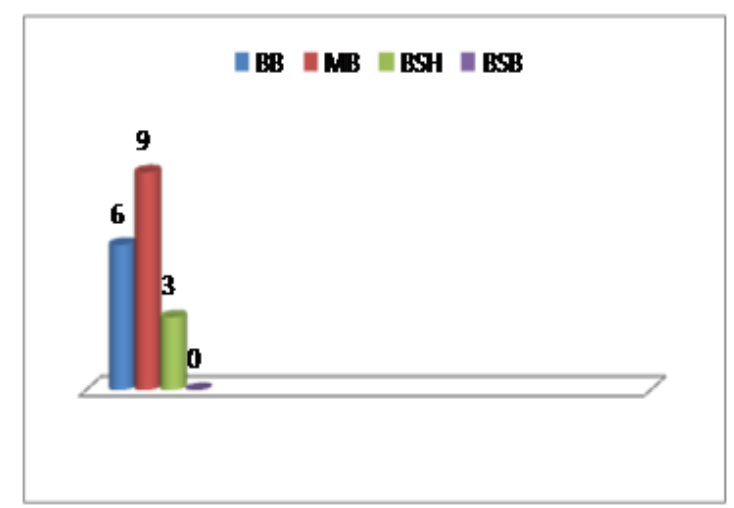

Gambar 1. Diagram Kemampuan Mengenal huruf Pra Siklus Anak kelompok B di TKK Rherhedja 2

\section{Deskripsi Hasil Pelaksanaan Tindakan Siklus II}

Pada tahap ini peneliti menyiapkan RPPH. Selain itu, peneliti menyiapkan kartu huruf dan lembar pengamatan yang akan digunakan pada saat pembelajaran. Yang perlu dilaksanakan dalam tindakan ini adalah membuat refleksi awal, mengindentifikasi permasalahan, merumuskan permasalah secara operasional yang relevan, merumuskan hipotesis tindakan yang bersifat tentatif yang memungkinkan anak mengalami perubahan dan menetapkan serta merumuskan tindakan.

\section{a. Perencanaan}

Pada tahap ini penulis mempersiapkan RPPH, dan kartu huruf.

b. Tindakan 
1. Kegiatan Awal

a. Berdoa

b. Absen

c. Guru menyiapkan peserta didik secara psikis dan fisik untuk mengikuti proses pembelajaran.

d. Apersepsi sebagai pengggalian pengetahuan awal siswa terhadap materi yang akan diajarkan.

e. Guru menyampaikan tujuan pembelajaran dan pokok-pokok materi yang akan dipelajari.

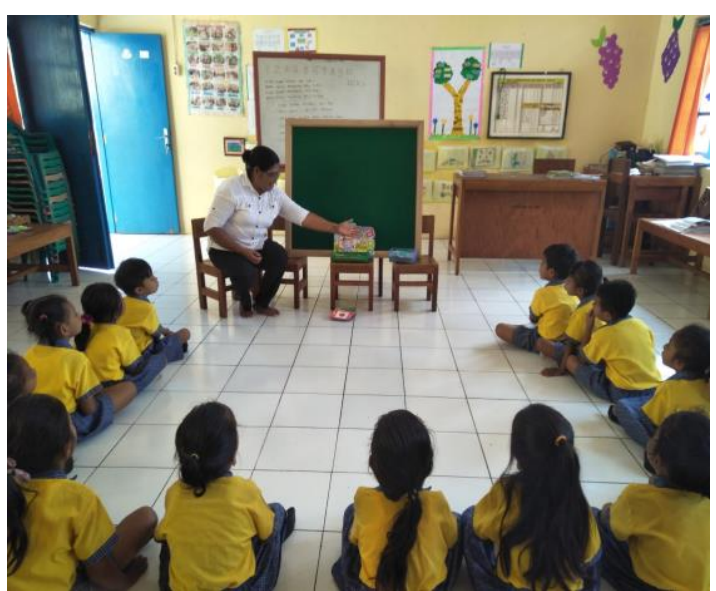

Gambar 2. Penjelasan tentang bentuk huruf.

\section{Kegiatan Inti}

a. anak diperkenalkan huruf .

b. Guru dan anak memperhatikan bentuk huruf

c. Guru melakukan penilaian kepetapan anak mengenal huruf.

d. Guru mengadakan refleksi dengan bertanya kepada anak tentang hal-hal yang dirasakan belum dipahami dengan baik.

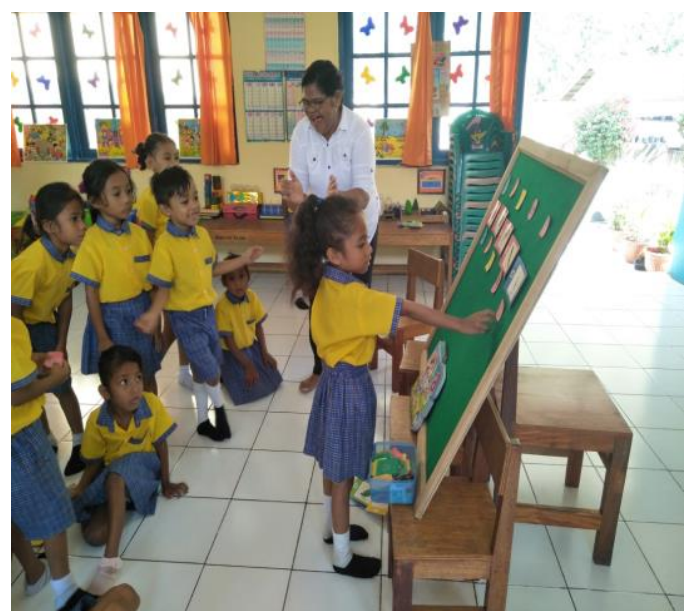

Gambar 3. Kegiatan inti

3. Kegiatan akhir

a. Guru memberikaan kesimpulan terhadap hasil anak

b. Guru memberikan tugas rumah.

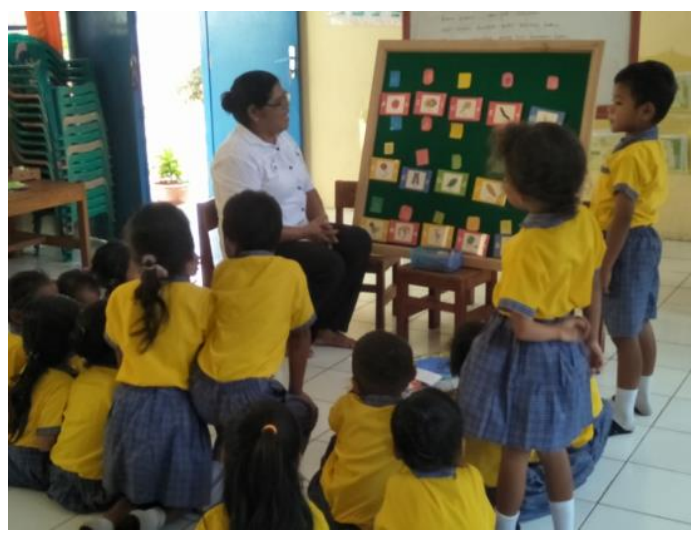

Gambar 4. Kegiatan penutup

c. Observasi

Tahap pengamatan (observasi) ini meliputi aktivitas guru dan aktivitas anak yang dilaksanakan pada saat tahap pelaksanaan tindakan sedang berlangsung, (keduanya berlangsung pada waktu yang sama). Melakukan observasi sesuai dengan format yang sudah di siapkan dan mencatat semua hal-hal yang diperlukan yang terjadi selama pelaksanaan tindakan berlangsung. Hasil penilaian aktivitas guru dapat dilihat pada tabel berikut ini. 
PRIMA MAGISTRA: Jurnal Ilmiah Kependidikan Nomor 1, Volume 1, April 2020, hal 116-124

Tabel 2

Aktifitas Guru dalam Menggunakan Media Papan Flanel Siklus I

\begin{tabular}{|c|c|}
\hline Aspek Yang Diobservasi & Skor \\
\hline $\begin{array}{l}\text { Langkah 1: Penerangan atau Pembelajaran. } \\
\text { Langkah pertama menentukan apakah penggunaan } \\
\text { media untuk keperluan informasi atau } \\
\text { pembelajaran. Media untuk keperluan informasi, } \\
\text { penerima informasi tidak ada kewajiban untuk } \\
\text { dievaluasi kemampuan atau keterampilannya dalam } \\
\text { menerima informasi, sedangkankan media untuk } \\
\text { keperluan pembelajaran penerima pembelajaran } \\
\text { harus menunjukkan kemampuannya sebagai bukti } \\
\text { bahwa mereka telah belajar. }\end{array}$ & 4 \\
\hline $\begin{array}{l}\text { Langkah 2: Tentukan Transmisi Pesan. Dalam } \\
\text { kegiatan ini dapat menentukan pilihan, apakah } \\
\text { dalam proses pembelajaran akan digunakan, 'alat } \\
\text { bantu pengajaran' atau 'media pembelajaran'. Alat } \\
\text { bantu pengajaran alat yang didesain, } \\
\text { dikembangkan, dan diproduksi untuk memperjelas } \\
\text { tenaga pendidik dalam mengajar. Sedangkan media } \\
\text { pembelajaran adalah media yang memungkinkan } \\
\text { terjadinya interaksi antara produk pengembang } \\
\text { media dan peserta didik/pengguna. }\end{array}$ & 4 \\
\hline $\begin{array}{l}\text { Langkah 3: Tentukan Karakteristik Pelajaran. } \\
\text { Menyusun disain pembelajaran, telah melakukan } \\
\text { analisis tentang mengajar, merumuskan tujuan } \\
\text { pembelajaran, telah memilih materi dan metode. } \\
\text { Selanjutnya dianalisis tujuan pembelajaran yang } \\
\text { telah ditentukan dalam ranah kognitif, afektif atau } \\
\text { psikomotor. Masing-masing ranah tujuan tersebut } \\
\text { memerlukan media yang berbeda. }\end{array}$ & 3 \\
\hline $\begin{array}{l}\text { Langkah 4: Klasifikasi Media. Pilihan Media sesuai } \\
\text { dengan karakteristik materi. }\end{array}$ & 3 \\
\hline $\begin{array}{l}\text { Langkah 5: Analisis karakteristik masing-masing mı } \\
\text { Media pembelajaran yang digunakan mencapai tu } \\
\text { pembelajaran yang telah ditetapkan, dari berb } \\
\text { alternatif kemudian dipilih media yang paling tepat. }\end{array}$ & 3 \\
\hline Total Skor & 20 \\
\hline Skor Perolehan & 15 \\
\hline Prosentasi & 75 \\
\hline Kategori Keberhasilan & Baik \\
\hline
\end{tabular}

Berdasarkan data hasil observasi aktifitas guru di atas dapat disimpulkan bahwa keberhasilan guru dalam menggunakan media papan flanel untuk meningkatkan kemampuan anak mengenal huruf pada siklus I adalah 75 $\%$ atau termasuk baik. Selanjutnya dapat dilihat pada gambar sebagai berikut:

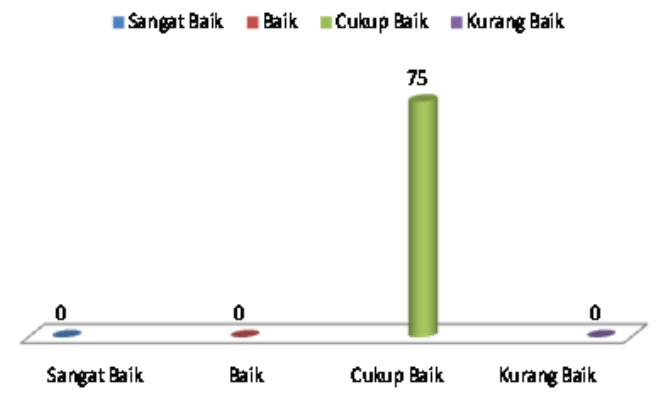

Gambar 5. Diagram keberhasilan guru menggunakan media papan flanel

Untuk mengetahui apakah setelah guru menggunakan media papan flanel anak mampu mengenal huruf maka berikut ini akan disajikan dapat hasil pengamatan sebagai gambaran kemampuan anak kelompok B di TKK Rherhedja 2 sbb:

Tabel 3

Hasil Observasi Kemampuan Anak Mengenal Huruf Pada anak Kelompok B TKK Rherhedja 2

\begin{tabular}{|c|c|c|c|c|}
\hline \multirow[t]{2}{*}{ Nama anak } & \multicolumn{4}{|c|}{ Nilai } \\
\hline & $\mathrm{BB}$ & $\mathrm{MB}$ & $\mathrm{BSH}$ & $\mathrm{BSB}$ \\
\hline MHR & & & $* * * 3$ & \\
\hline KSO & & & $* * * 3$ & \\
\hline MKJ & & & $* * * 3$ & \\
\hline EAM & & & $* * * 3$ & \\
\hline \multicolumn{5}{|l|}{ YYP } \\
\hline PLI & & & $* * * 3$ & \\
\hline FAT & & $* * 2$ & & \\
\hline EKR & & & $* * * 3$ & \\
\hline YBP & & $* * 2$ & $* * *$ & \\
\hline AMS & & $* * 2$ & & \\
\hline LAN & & $* * 2$ & & \\
\hline FJW & & & $* * * 3$ & \\
\hline AMG & & $* * 2$ & $* * * 3$ & \\
\hline \multicolumn{5}{|l|}{ MGS } \\
\hline MFD & & & $* * * 3$ & \\
\hline DBB & & $* * 2$ & & \\
\hline FVP & & & $* * * 3$ & \\
\hline \multicolumn{5}{|l|}{ FJW } \\
\hline Jumlah & 0 & 6 & 12 & \\
\hline
\end{tabular}

Ket: BB: (Belum Berkembang *1) MB (mulai berkembang**2), BSH Berkembang sesuai Harapan***3) BSB (Berkembang sangat baik $* * * * 4)$

Berdasarkan data siklus I di atas dapat diketahui bahwa kemampuan mengenal huruf anak kelompok $\mathrm{B}$ adalah sebagai berikut: belum berkembang atau $* 1$ sebanyak 0 orang atau $0 \%$, Mulai berkembang 6 orang atau $33,33 \%$ dan baru sesuai harapan 12 orang atau $66,67 \%$ serta berkembang sangat baik 0 anak.

Berdasarkan data di atas maka refkelsi peneliti adalah lebih memaksimalkan menggunakan media papan flanel untuk 
PRIMA MAGISTRA: Jurnal Ilmiah Kependidikan Nomor 1, Volume 1, April 2020, hal 116-124

meningkatkan kemampuan anak dalam mengenal huruf.

\section{Deskripsi Hasil Pelaksanaan Tindakan Siklus II}

Seperti pada siklus I kegiatan persiapan yang dialkukan sebelumnya adalah peneliti menyiapkan RPPH, peneliti membuat Lembar Kerja Siswa berupa gambar cerita yang akan diceritakan pada saat pembelajaran.

\section{a. Perencanaan}

Kegiatan perencanaan yang dilakukan pada siklus II sama seperti pada siklus I dengan materi yang sama. Pada tahap siklus II ini, dilakukan untuk memperbaiki kekurangan pada siklus 1 yang belum teratasi. Pada tahap ini penulis mempersiapkan RPPH, dan lembar kerja siswa berupa cerita.

b. Tindakan

a. Kegiatan Awal

1. Berdoa

2. Ambil absen

3. Guru menyiapkan peserta didik secara psikis dan fisik untuk mengikuti proses pembelajaran.

4. Apersepsi sebagai pengggalian pengetahuan awal siswa terhadap materi yang akan diajarkan.

5. Guru menyampaikan tujuan pembelajaran dan pokok-pokok materi yang akan dipelajari.

6. Penjelasan bentuk huruf.

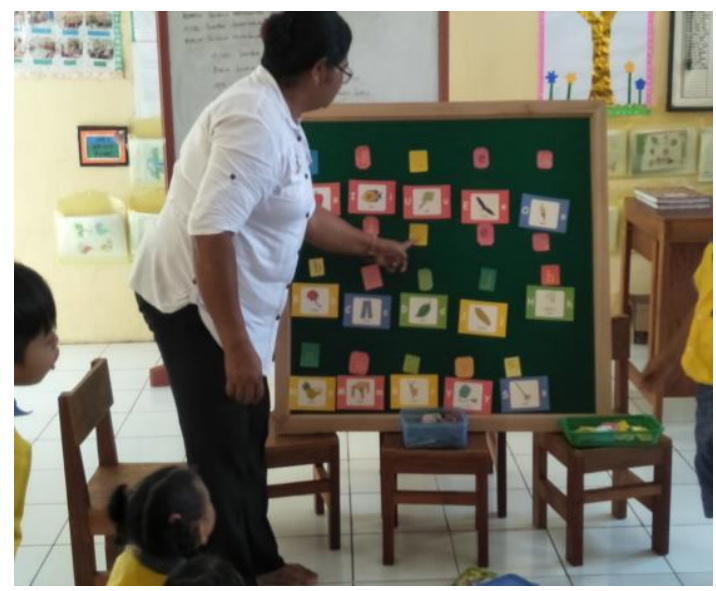

Gambar 6. Kegiatan Awal Siklus II b. Kegiatan Inti

a. anak mengenal huruf.

b. Guru membantu anak yang belum mampu.

4. Guru melakukan penilaian proses saat anak menempel huruf.

5. Guru mengadakan refleksi dengan bertanya kepada anak tentang halhal yang dirasakan belum dipahami dengan baik.

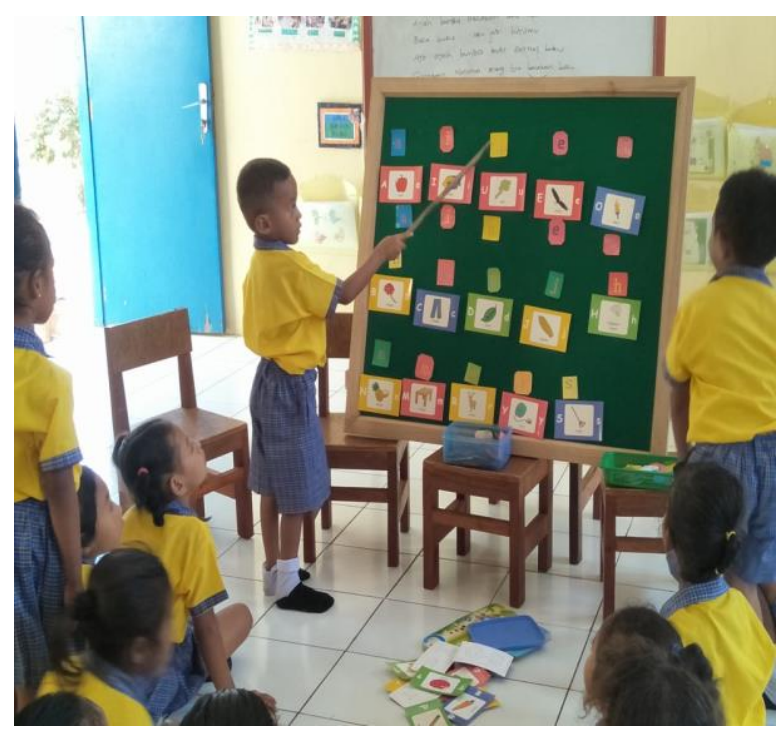

Gambar 7. Kegiatan Inti Siklus II

4. Kegiatan akhir

1. Guru memberikaan kesimpulan terhadap hasil cerita anak

2. Guru memberikan tugas latihan bercerita di rumah.

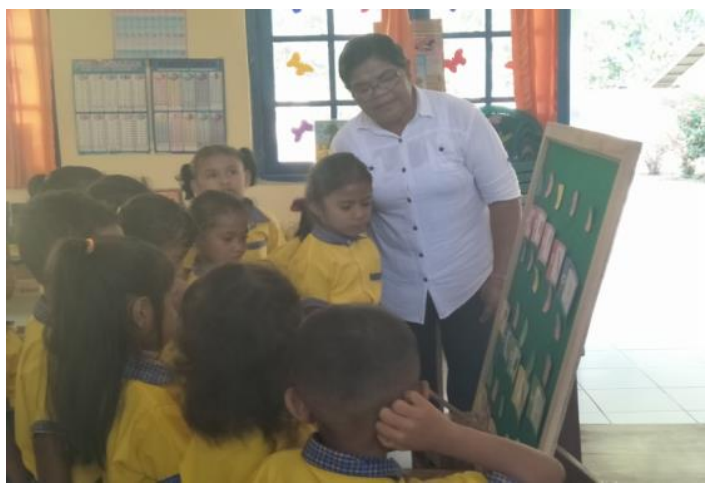

Gambar 8. Kegiatan Akhir Siklus II 


\section{c. Kegiatan penutup}

\section{c. Observasi}

Tahap pengamatan (observasi) ini meliputi aktivitas guru dan aktivitas anak yang dilaksanakan pada saat tahap pelaksanaan tindakan sedang berlangsung, (keduanya berlangsung pada waktu yang sama).

Observasi dilakukan sesuai dengan format yang sudah di siapkan dan mencatat semua hal-hal yang diperlukan yang terjadi selama pelaksanaan tindakan berlangsung. Hasil penilaian aktivitas guru dapat dilihat pada tabel berikut ini.

Tabel 4

Aktifitas Guru Dalam Menerapkan Media papan Flanel Siklus II

\begin{tabular}{|c|c|}
\hline Aspek Yang Diobservasi & Skor \\
\hline $\begin{array}{l}\text { Langkah 1: Penerangan atau Pembelajaran. Langkah } \\
\text { pertama menentukan apakah penggunaan media } \\
\text { untuk keperluan informasi atau pembelajaran. Media } \\
\text { untuk keperluan informasi, penerima informasi tidak } \\
\text { ada kewajiban untuk dievaluasi kemampuan atau } \\
\text { keterampilannya dalam menerima informasi, } \\
\text { sedangkankan media untuk keperluan pembelajaran } \\
\text { penerima pembelajaran harus menunjukkan } \\
\text { kemampuannya sebagai bukti bahwa mereka telah } \\
\text { belajar. } \\
\text { Langkah 2: Tentukan Transmisi Pesan. Dalam } \\
\text { kegiatan ini dapat menentukan pilihan, apakah dalam } \\
\text { proses pembelajaran akan digunakan 'alat bantu } \\
\text { pengajaran' atau 'media pembelajaran'. Alat bantu } \\
\text { pengajaran alat yang didesain, dikembangkan, dan } \\
\text { diproduksi untuk memperjelas tenaga pendidik dalam } \\
\text { mengajar. Sedangkan media pembelajaran adalah } \\
\text { media yang memungkinkan terjadinya interaksi } \\
\text { antara produk pengembang media dan peserta } \\
\text { didik/pengguna. }\end{array}$ & 4 \\
\hline $\begin{array}{l}\text { Langkah 3: Tentukan Karakteristik Pelajaran. } \\
\text { Menyusun disain pembelajaran, telah melakukan } \\
\text { analisis tentang mengajar, merumuskan tujuan } \\
\text { pembelajaran, telah memilih materi dan metode. } \\
\text { Selanjutnya dianalisis tujuan pembelajaran yang telah } \\
\text { ditentukan dalam ranah kognitif, afektif atau } \\
\text { psikomotor. Masing-masing ranah tujuan tersebut } \\
\text { memerlukan media yang berbeda. }\end{array}$ & 4 \\
\hline $\begin{array}{l}\text { Langkah 4: Klasifikasi Media. Pilihan Media sesuai } \\
\text { dengan karakteristik materi. }\end{array}$ & 4 \\
\hline $\begin{array}{l}\text { Langkah 5: Analisis karakteristik masing-masing mı } \\
\text { Media pembelajaran yang digunakan mencapai tu } \\
\text { pembelajaran yang telah ditetapkan, dari berbagai alter } \\
\text { kemudian dipilih media yang paling tepat. }\end{array}$ & \\
\hline Total Skor & 20 \\
\hline Skor Perolehan & 19 \\
\hline Prosentasi & 95 \\
\hline \multicolumn{2}{|l|}{ Kategori Keberhasilan $\quad$ Sangat Baik } \\
\hline
\end{tabular}

Ket: Ket: SB: Sangat Baik (4),B : Baik (3), C: Cukup (2),K: Kurang (1)

Berdasarkan data hasil observasi aktifitas guru di atas dapat disimpulkan bahwa keberhasilan guru dalam menggunakan media papa flanel untuk meningkatkan kemampuan anak mengenal huruf pada siklus II adalah 95 $\%$ atau termasuk sangat baik. Selanjutnya dapat dilihat pada diagram 4.2 sebagai berikut:

Untuk mengetahui kemampuan anak dalam mengenal huruf vokal dan konsonan setelah digunakan media papan flanel maka berikut ini akan disajikan data sbb:

Tabel 5

Hasil Observasi Kemampuan Anak Mengenal Huruf Pada anak Kelompok B TKK Rherhedja 2

\begin{tabular}{ccccc}
\hline Nama anak & \multicolumn{3}{c}{ Nilai } \\
\cline { 2 - 6 } & BB MB & BSH & BSB \\
\hline MHR & & & $* * * * 4$ \\
KSO & & & $* * * * 4$ \\
MKJ & & & $* * * * 4$ \\
EAM & & & $* * * * 4$ \\
YYP & & $* * * 3$ & \\
PLI & & $* * * 3$ & \\
FAT & & & & $* * * * 4$ \\
EKR & & & & $* * * * 4$ \\
YBP & & & & $* * * * 4$ \\
AMS & & & $* * * 3$ & \\
LAN & & & $* * * 3$ & \\
FJW & & & $* * * 3$ & \\
AMG & & & & $* * * * 4$ \\
MGS & & & & $* * * * 4$ \\
MFD & & & $* * * 3$ & \\
DBB & & & $* * * 3$ & \\
FVP & & & & $* * * * 4$ \\
FJW & & & $* * * 3$ & \\
\hline Jumlah & 0 & 0 & 8 & 10 \\
\hline
\end{tabular}

Ket: BB: (Belum Berkembang *1) MB (mulai berkembang**2), BSH Berkembang sesuai Harapan***3) BSB (Berkembang sangat baik****4)

Berdasarkan data di atas dapat diketahui bahwa kemampuan mengenal huruf anak kelompok B setelah digunakan media papan flanel adalah sebagai berikut: belum berkembang atau $* 1$ sebanyak 0 orang atau 0 $\%$, Mulai berkembang 0 orang atau $0 \%$ dan Baru sesuai harapan 8 orang atau $44,44 \%$ serta berkembang sangat baik 10 anak atau 55,56\%.

c. Refleksi 
Refleksi pada siklus II mengungkapkan bahwa telah terjadi peningkatan kemampuan mengenal huruf vokal dan konsonan sehingga tidak dilanjutkan pada siklus berikutnya.

\section{B. PEMBAHASAN}

Media pembelajaran adalah salah satu alat bantu utama untuk membantu guru mengkonkritkan materi pembelajaran. Keberadaan media pembelajaran dalam jenjang pendidikan usia dini sangat mempengaruhi daya serab anak memahami apa yang menjadi tema pembelajaran.Kreatifitas guru dalam menggunakan media dalam pembelajaran untuk mempermudah anak memahami materi merupakan syarat profesionalitas yang ada pada guru dan menjadi unjuk kerja dalam implentasi pembelajaran.

Media sebagai alat peraga yang sering disebut," audio visual aid " adalah alat yang dapat diserap oleh mata, telinga sebagai alat bantu dalam proses belajar mengajar sehingga mencapai hasil yang optimal. Alat peraga atau alat bantu pengajaran adalah sesuatu yang digunakan dalam kegiatan belajar mengajar agar dapat berlangsung dengan baik, maksudnya membantu anak agar dapat memahami dan menerima pelajaran dengan baiak. Menggunakan alat peraga dengan kecakapan dan ketrampilan yang cukup sehingga kegiatan belajar mengajar dapat berjalan dengan baik dan mudah diterima oleh anak didik.

Alat peraga adalah, suatu alat yang dapat diserap oleh mata dan telinga Dengan tujuan membantu guru agar proses belajar mengajar siswa lebih efektif dan efisien (Sudjana, 2002). Alat peraga dalam mengajar memegang peranan penting sebagai alat bantu untuk menciptakan proses belajar mengajar yang efektif.

Proses belajar mengajar ditandai dengan adanya beberapa unsur antara laian tujuan,bahan, metode dan alat, serta evaluasi. Unsur metode dan alat merupakan unsur yang tidak bisa dilepaskan dari unsur lainnya yang berfungsi sebagai cara atau tehnik untuk mengantarkan sebagai bahan pelajaran agar sampai pada tujuan. Dalam pencapaian tersebut,peranan alat bantu atau alat peraga memegang peranan yang penting sebab dengan adanya alat peraga ini bahan dengan mudah dapat dipahami oleh siswa. Dalam proses belajar mengajar alat peraga dipergunakan dengan tujuan membantu guru agar proses belajar siswa lebih efektif dan efisien.

Berdasarkan data hasil obervasi tentang penggunaan media papan flanel pada siklus I sebesar $75 \%$ atau kategori baik dan pada siklus II meningkat menjadi $95 \%$ atau kategori sangat baik. Data hasil observer ini menjadi indikator keberhasilan peneliti bahwa peneliti sudah mampu menggunakan media papan flanel secara baik dalam pembelajaran di TKK Rherhedja. Dalam bentuk tabel dapat disajikan sbb:

Program pendidikan anak usia dini difokuskan pada bermain dan belajar. Walaupun demikian semua kegiatan direncakan secara tertulis dalam RPPH sebagai dasar pembelajaran. Belajar menulis harus diawali dari mengenal huruf baik vokal dan konsonan. Hal ini menjadi pengetahuan dasar bagi anak yang akan menulis.

Penelitian ini difokuskan pada kemampuan mengenal huruf dengan menggunakan media papan flanel. Data hasil penelitian dari pra siklus, siklus I dan II menunjukan bahwa terjadi peningkatan secara baik.

Dari 18 anak pada Pra siklus anak yang baru berkembang (BB) 6 orang atau 33,33\%, anak yang mulai berkembang (MB) 9 orang atau 50\%, anak berkembang sesuai harapan (BSH) 3 orang atau 16,67 dan anak berkemnag sangat baik (BSB) 0 orang atau $0 \%$.

Setelah digunakan media papan flanel pada siklus I terjadi peningkatan sbb: anak yang baru berkembang (BB) 0 orang atau $0 \%$, anak yang mulai berkembang (MB) 6 orang atau $33,33 \%$, anak berkembang sesuai harapan (BSH) 12 orang atau $66,67 \%$. Pada Siklus II terjadi peningkatan kemampuan mengenal huruf dengan rincian: anak yang baru berkembang (BB) 0 orang atau $0 \%$, anak yang mulai berkembang (MB) 0 orang atau $0 \%$, anak berkembang sesuai harapan (BSH) 8 
PRIMA MAGISTRA: Jurnal Ilmiah Kependidikan Nomor 1, Volume 1, April 2020, hal 116-124

orang atau 44.44.dan anak berkemnag sangat baik (BSB) 10 orang atau 55,56\%. Selanjutnya dapat dilihat pada tabel 6 berikut ini:

$$
\text { Tabel } 6
$$

Kemampuan Mengenal Huruf anak Prasiklus, Siklus I

\begin{tabular}{ccccccc}
\multicolumn{7}{c}{ dan II } \\
$\begin{array}{c}\text { Hasil } \\
\begin{array}{c}\text { Menggamb } \\
\text { ar }\end{array}\end{array}$ & $\begin{array}{c}\text { Prasiklu } \\
\text { s }\end{array}$ & $\%$ & $\begin{array}{c}\text { Siklu } \\
\text { s I }\end{array}$ & $\%$ & $\begin{array}{c}\text { Siklu } \\
\text { s II }\end{array}$ & $\%$ \\
\hline BB & 6 & $\begin{array}{c}33,3 \\
3\end{array}$ & 0 & 0 & 0 & 0 \\
MB & 9 & 50 & 6 & $\begin{array}{c}33.3 \\
3\end{array}$ & 0 & 0 \\
BSH & 3 & $\begin{array}{c}16,6 \\
7\end{array}$ & 12 & $\begin{array}{c}66,6 \\
7\end{array}$ & 8 & $\begin{array}{c}44,4 \\
4\end{array}$ \\
BSB & 0 & 0 & 0 & 0 & 10 & $\begin{array}{c}50,6 \\
6\end{array}$ \\
\hline JUMLAH & 18 & & 18 & & 18 & \\
\hline
\end{tabular}

Berdasarkan tabel di atas, peningkatan kemampuan mengenal huruf dapat digambarkan dalam bentuk diagram di bawah ini.

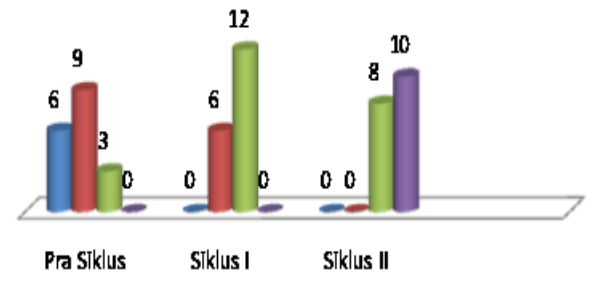

Gambar 9 Diagram Peningkatan Kemampuan Mengenal Huruf anak kelomk B di TKK Rherhedja 2

\section{SIMPULAN DAN SARAN}

Berdasarkan hasil penelitian yang telah dipaparkan di atas, maka dapat disimpulkan bahwa kemampuan anak kelompok B TKK Rherhedja 2 dalam mengenal huruf vokal dan konsonan dapat ditingkatkan melalui penggunaan media papan flanel.

\section{DAFTAR PUSTAKA}

Ardiansyah, Rifky. (2012). Pemanfaatan Media Pembelajaran. Karya Ilmiah Universitas Negeri Malang.

Cleophas, Frans. (2011). Penggunaan Media Pembelajaran Yang Tepat Dapat
Menunjang Keberhasilan Dalam Proses Pembelajaran.

Hamalik, Oemar. (2007). Manajemen Pelatihan Ketenagakerjaan: Pendekatan Terpadu Pengembangan Sumber Daya Manusia. Jakarta: Bumi Aksara.

Kuswanto, Goto. (2012). Pemanfaatan Media Pembelajaran untuk Meningkatkan Efektivitas Diklat oleh Widyaiswara.

Sadiman, Arief S. (dkk). (2009). Media Pendidikan : Pengertian, Pegembangan dan Pemanfaatannya. Jakarta : Raja Grafindo Persada.

Supriatna, Dadang. (2009). Pengenalan Media Pembelajaran. Pusat Pengembangan Dan Pemberdayaan Pendidik DanTenaga Kependidikan Taman Kanak KanakDan Pendidikan Luar Biasa. 